INVESTING INTH HEALTH OF CHILDREN

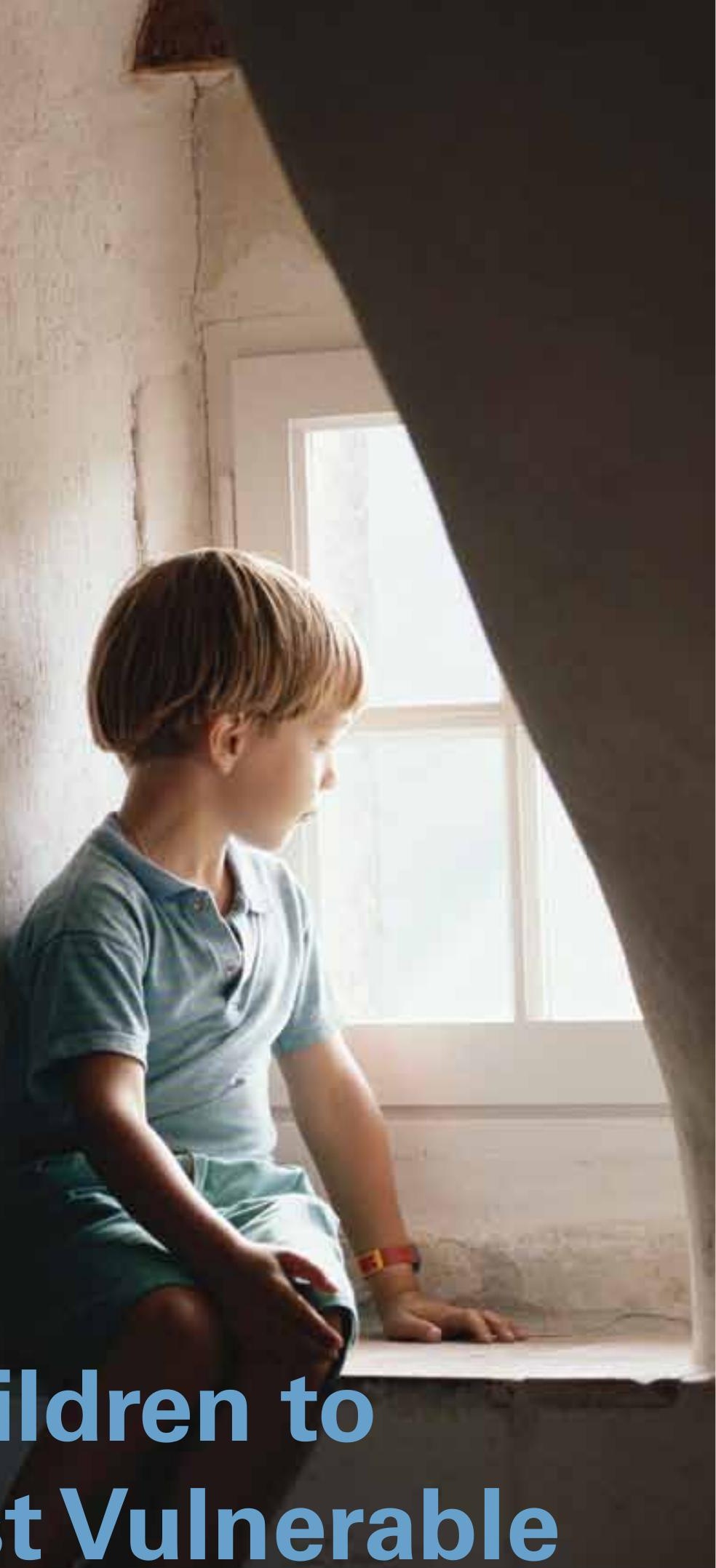

Kerry McCuaig 
A young mother of three, Susan came to the early learning centre in the local school at the urging of her social worker. In Susan's words, "I went to get my worker off my case. I hated walking in the doors of that red brick building which brought back bad feelings of my own experiences at school" (names changed to protect privacy; Morrison et al. 2012: 14). Susan's oldest daughter has been diagnosed with autism; her two younger children have developmental delays. She wants more than anything to give her children a different upbringing than she experienced but by her own assessment: "Most days, I'm not a very good mother."

An extensive intervention plan has been developed for the children, which now includes an early interventionist, speech and occupational therapy, a physiotherapist and social worker. But to Susan, the help is sometimes a burden. "It felt like we

\section{In the integrated-centre model,}

specialists do not work in isolation with the child but involve the family and the entire staff team.

were always running from place to place. A lot of times I just cancelled because I was too tired" (Morrison et al. 2012: 14). According to the case file this family is well served. But for all the help offered, Susan doesn't consider herself a more competent parent. She feels observed, judged and a failure. From a service perspective, it is counterproductive to refer a child to a support program if the parent is doesn't attend.

Fortunately, the early learning centre has provided Susan with some welcomed options. It is one of a dozen in the Maritime Provinces now showcasing the benefits of delivering early education, child care, family support and intervention programs from a service platform anchored to local schools. Called Early Childhood Development Centres, they are designed to inform public policy by showcasing effective forms of early childhood service delivery. Operations and research are supported by the Margaret and Wallace McCain Family Foundation in partnership with the governments of New Brunswick, Nova Scotia and Prince Edward Island. Modelled on the 10-year-old Toronto First Duty experiment, the centres offer a seamless continuum of supports, beginning with pre- and post-natal information and nutrition resources, parent-infant activities and programs that encourage parents to choose appropriate behaviour guidance and to read and talk more with their children. As children progress through play groups to enrol in the flexible preschool program and move into the elementary grades, they and their families have continuous access to child care, health screening, special needs interventions and family counselling and referrals to employment, immigration and housing services.
By integrating staffing, resources, administration and facilities, the school, health, family support and community partners are able to create a nurturing and supportive cocoon. Children are not segregated from their families. The family and staff form a devel-

A great change is coming over childhood in the world's richest countries. Today's rising generation is the first in which a majority is spending a large part of early childhood in some form of out-of-home child care. At the same time, neuro-scientific research is demonstrating that loving, stable, secure and stimulating relationships with caregivers in the earliest months and years of life are critical for every aspect of a child's development. Taken together, these two developments confront public and policy makers in OECD countries with urgent questions. Whether the child care transition will represent an advance or a setback - for today's children and tomorrow's world - will depend on the response.

UNICEF. 2008. The Child Care Transition, Innocenti Report Card 8, 2008. Florence, Italy: UNICEF Innocenti Research Centre.

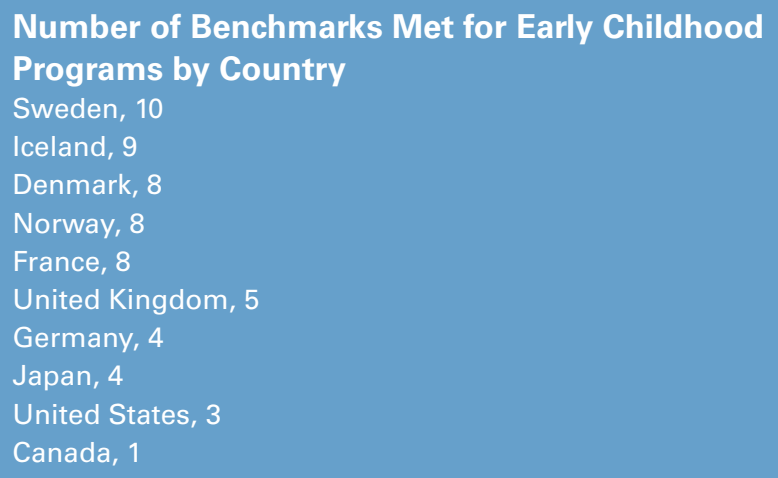

Source: Reproduced with permission from UNICEF (2008).

opmental team. Parents in integrated programs consider the school part of their family's support network. They report feeling more empowered to engage with staff and show more positive interactions with their children at home. This capacity building works for parents who are new to Canada as well as for those born here, and for families at risk and those with adequate resources. Research also suggests that the integrated model is able to serve more families in ways in which they want to be served and with higher-quality programming for the same costs as traditional "siloed" delivery. (Information on programming and research is available at Toronto First Duty's website: www.toronto.ca/firstduty.)

"I didn't expect to be treated so kindly from the minute we arrived," Susan relates. "They asked our advice about our 
kids and asked us if we could help them out too. It was a good feeling, and we have been at the centre since. The best part is we no longer have to take a bunch of buses for all of the kids' appointments. Everyone meets us at the centre. I don't miss our appointments anymore" (Morrison et al. 2012: 14). In addition to compliance, evaluators are finding other positive spillovers. Short-term, sporadic interventions are not sufficient for sustainable improvement. In the integrated-centre model, specialists do not work in isolation with the child but involve the family and the entire staff team, raising the bar in everyone's practice

\section{The reduced need for social supports coupled with the tax revenues from mothers who are able to work because of low-cost children's programming pays for the entire cost of Quebec's system.}

and creating an environment that reinforces interventions. The intensity and consistency provided by the entire staff team often reduces the length of time the child requires specialized supports. Professionals are relieved of travel and administrative duties, allowing them to spend more time with the children and families.

Supports provided in early childhood can change developmental trajectories, thereby influencing life outcomes. Susan's family appears to be on a new path; too many others are still running around to appointments. Parents and kids are frustrated, and professionals are often disheartened. And these are the lucky ones who receive our attention. What about those children whose exceptionalities are not identified, who linger on waiting lists or who are deemed "good enough"?

\section{Changing Families, Stagnating Services}

The needs of modern families have changed; the services designed to support them have not. Children's programming in Canada is divided into three distinct streams - education, child care, and family and intervention supports. All promote the healthy development of children as their primary goal, yet they have little, or no, interaction. There are pockets of innovation and increased levels of investment, but service overlap prevails alongside large gaps. Each stream has its own bureaucracy, culture and mandate. The result is service silos. Children and families don't experience their lives in silos; their needs can't be dissected and addressed in isolation.

In a comprehensive review of the early childhood systems in 20 of its member countries, the Organisation for Economic Co-operation and Development (OECD 2006) found Canada spends the lowest amount per child on early childhood programs. As a result, Canadian children are much older than their European counterparts when they enrol in kindergarten and are the least likely to access child care, preschool or other early years services. (Starting Strong [OECD 2006])

Siloed delivery is an impediment. The OECD review found that in jurisdictions where the policy and delivery of education, child care and related supports are divided, the following similar challenges prevail:

- Coverage is sparse.

- Not all families receive the services for which they are eligible.

- Service location and affordability are barriers.

- Services hours and parents' work schedules often conflict.

- Families with multiple needs have difficulty fitting services together.

- Families lose needed services as children age or their circumstances change.

Service providers have the following challenges:

- There is no ongoing contact with families during their children's early years.

- Inflexible mandates and funding criteria leave providers unable to provide cohesive support.

- Services are funded on the basis of inputs rather than outcomes, making it difficult to tailor services to families' diverse needs and circumstances.

- Services are typically focused on treatment, rather than prevention or health promotion, making it difficult to adapt to meet emerging needs.

- Payment is by piece work - the number of children seen rather than program quality or child outcomes.

Early Years Study (McCain and Mustard 1999), co-chaired by the Honourable Margaret Norrie McCain and Dr. Fraser Mustard in 1999, and Early Years Study 2 (McCain et al. 2007) brought the science of early human development to the attention of policy makers and the public. The researchers' work acknowledges that modern families need a modern support system, one that places the healthy development of children at the centre but also recognizes that children do not exist in isolation from their families. Noting that Canada's youngest citizens are highly underserved, the reports called on governments to invest in the early years at the same rate as for older children.

In Canada's family policy mix infancy receives some attention. Mothers are supported with universal pre- and post-natal care. Babies are screened at birth, and newborn home visiting is widespread. It is between the end of parental leave and the beginning of schooling that supports break down and public policy is confused about what to do.

Early Years Study 3 (McCain et al. 2011) recommends building on the asset we already have in public education. It envisions the transformation of elementary schools into child and 
family centres that work with parents to welcome all children from infants to adolescents - and operate year round. The report argues that all the elements required to create a consolidated program that can actually work for families already exist in the hodgepodge of child care, public health, education and family support services. In an era of declining birth rates, expanding education's mandate to include younger children and families is cost-effective. It can help maintain the viability of schools, and in rural areas, preserving the school can preserve the community.

\section{Quebec's Natural Experiment}

Quebec has largely grasped this concept by enriching its parental leave and expanding educational child care for preschoolers. Full-day kindergarten begins at age five, and school boards are required to provide out-of-school care for children up to age 12. Academics from many fields have tracked the outcomes of Quebec's children's initiatives, and the results have been truly amazing. In just a decade, Quebec has gone from the bottom to the top on many important social indicators. Whereas it once had Canada's lowest female labour participation, it now has the highest (Roy et al. 2006). And whereas Quebec women were once less likely to attend post-secondary education than their counterparts in the rest of Canada, today they dominate (Roy et al. 2006). At the same time, student scores on standardized tests have gone from below the Canadian average to above it. Despite working more, Quebec women are also having more babies (Statistics Canada 2007, June 28), and Quebec dads are more involved in child rearing. Eighty-two percent of Quebec fathers take paid leave after the birth of their infants, compared with just $12 \%$ in the rest of the country (Statistics Canada 2011). In addition, childhood programs designed to allow mothers to work have slashed Quebec's child poverty rates by 50\% (Campaign 2000).

Finally, in an analysis that should catch the attention of policy makers everywhere, a team of Quebec economists revealed that the reduced need for social supports coupled with the tax revenues from mothers who are able to work because of low-cost children's programming pays for the entire cost of Quebec's system (Fortin et al. 2011).

Despites Quebec's documented success, policy makers in the rest of Canada and much of the public believe that families are managing just fine as is. Schools are scary enough places to send a six-year-old; they can't imagine allowing a two-year-old to attend. They fret over unmanageable costs and inexhaustible demands. The costs are high, but not in the way most imagine.

Most provinces determine children's readiness for school learning during kindergarten using the Early Development Instrument. Kindergarten teachers assess children on scales related to their social, emotional, cognitive and physical development. Country-wide data show that more than one in four kindergarten-aged children have vulnerabilities that make them more likely to fail in school (Offord Centre for Child Studies n.d.).

Abilities at school entry can be traced to experiences in and out of home, from birth on. How children do in kindergarten is a measure of the developmental opportunities available in a community, just as rates of infant mortality and low birth weight reflect the supports and resources available to pregnant women. Children who have trouble coping in kindergarten are less likely to graduate from high school or to go on to post-secondary education. As adults, they are more likely to fail in their personal relationships and have difficulties finding steady work. They are also more likely to become sick, addicted or depressed.

Poverty increases children's chances of delayed development, but it is not the only factor. Most vulnerable kids do not dwell in poverty; they live in middle- and upper-income households and neighbourhoods (Janus and Duku 2000). The learning gap between middle-income children and those born to the wealthy is just as big as the gap that separates low-income children from those of the middle class. Middle-class children, particularly boys (Gilmore 2010), drop out of school at alarming rates and with lifelong consequences (Stack 2011). In addition, income does not inoculate children against learning disabilities or lessthan-ideal home lives.

What difference could it make to families with young children - indeed to all of us - if every school welcomed kids of all ages? Supports in one generation can bring benefits to successive generations by breaking intergenerational cycles of illiteracy, poverty, social isolation and poor health. Let us revisit Susan's story: "I help the centre now by collecting clothes that are too small for my kids so they can be given to someone else. The centre helps us when we need it and shows us how we can help others when they need it too. We like it here and wouldn't go anywhere else because our kids are happy and learning a lot for school" (Morrison et al. 2012: 14). In her short interview, Susan identifies daily challenges that, if not addressed, could become long-term problems. Instead of being stressed and depressed, she has escaped the isolation that fulltime caregivers often experience. Rather than bequeathing her distaste for school, Susan's new-found positivism is being conveyed to her children.

Stress and depression are not restricted to those who are struggling financially, new immigrants or single parents. The "sandwich generation" is looking after both young children and aging parents. These individuals are working longer and harder, and job security is not an option (Kershaw 2011). A survey by the Conference Board of Canada found that the most frazzled employee is the professional mother (Higgins and Duxbury).

Stressed-out parents are not great for their children. Stress disrupts parents' ability to manage their own conduct, leaving them with fewer resources to regulate their children's behaviour. The more harried parents are, the less likely they are able to engage positively with their children. Chronic parental stress "drips down" on children. Researchers have connected 
chronic parental stress to the poor academic record of their children (Harold 2007). Conversely, researchers have found that parents whose children attend programs that are integrated into their school are much less anxious than their neighbours whose kids are in the regular, jumbled system (Toronto First Duty 2009). Direct gains have also been documented for

\section{Just as healthcare costs are unmanageable without health promotion, cleaning up after children who have fallen through the cracks is equally unsustainable.}

children. Evaluations of Sure Start in the United Kingdom (Siraj-Blatchford and Siraj-Blatchford 2009), Communities for Children in Australia (Government of Australia n.d.) and Toronto First Duty (2008) found that children in neighbourhoods with integrated children's services showed better social development, more positive social behaviour and greater independence/self-regulation compared with children living in similar areas without an integrated program.

Canadians must make the hard and important job of raising children a little easier. As a society, we cannot have it all. We rely on women's labour and expect families to shoulder the social and financial load of rearing the next generation. But we pay a big price when families flounder and their children get left behind. Just as healthcare costs are unmanageable without health promotion, cleaning up after children who have fallen through the cracks is equally unsustainable.

We are making some progress. An environmental scan featured in Early Years Study 3 (McCain et al. 2011) found that provincial spending on early childhood programs has doubled since the OECD delivered its failing grade to Canada in 2006. Half of all three-year-olds now regularly attend a preschool program, up from $20 \%$ in 2006. But spending more doesn't necessarily mean spending smart. Split oversight and delivery still require too many parents to piece together arrangements to cover their work schedules. The results are stressful for children and parents alike, but they also negate the wonderful payback that comes from delivering early education in a way that simultaneously supports children's learning and their parents' work.

\section{Index Reveals Progress in Systems Design}

To monitor development in the provinces' early childhood systems, the authors of Early Years Study 3 created the Early Childhood Education Index, a 15-point scale that assesses the governance, funding and accountability of early childhood programming by province. In 2011, only three jurisdictions made it past the halfway mark in this first iteration (Figure 1). Yet there are reasons for optimism. In 2006, Quebec would have stood alone. At that time, only three provinces offered full-day kindergarten; today six do. Province-wide curricula anchored in learning through play were the exception instead of the norm. No province had merged oversight for education and child care; today four have a single lead ministry, and the monitoring and reporting of vulnerability in preschool-aged children is no longer a rarity. We now have many examples of good practice and the steps that jurisdictions took to achieve their results. Their experiences can serve as a guide to others. The index does not suggest that there is only one route to success. Indeed, the two leading jurisdictions (Quebec and Prince Edward Island) reached their destinations using very different methods. The index is now housed at the Atkinson Centre at the Ontario Institute for Studies in Education, University of Toronto. It will undergo additional validation before going into the field again in 2013-2014.

\section{FIGURE 1. \\ Early Childhood Education Index, total scores for 2011}

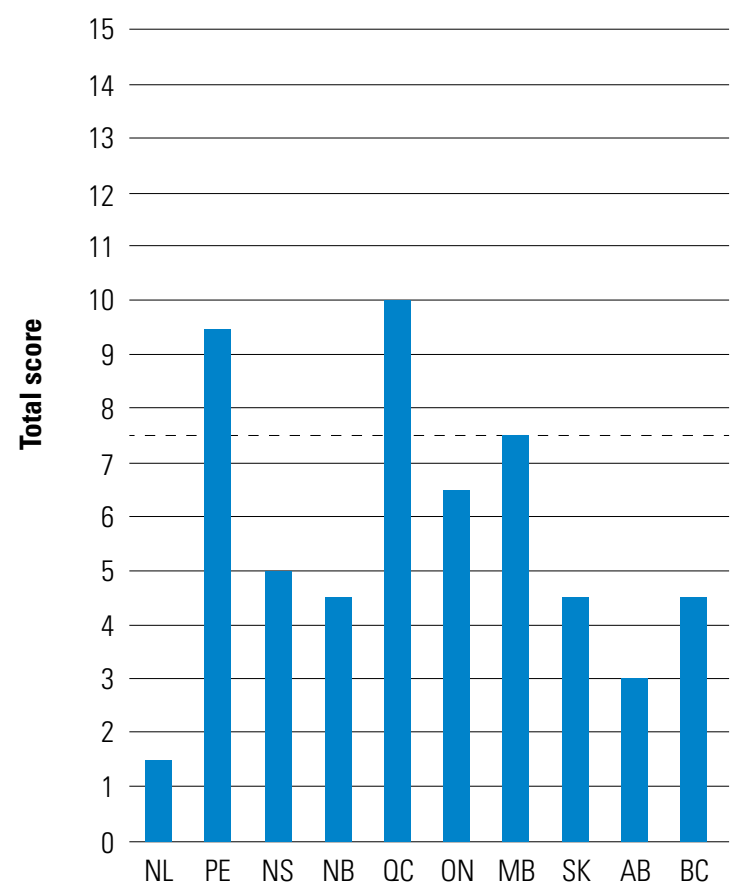

Jurisdiction

Source: Reproduced with permission from the Margaret and Wallace McCain Family Foundation.

An explosion of made-in-Canada research contributes to an understanding of lifelong learning and a life-cycle approach to human development. It provides a powerful policy framework that recognizes that support interventions are cumulative. At the 
provincial level, governments must lead with coherent resources and oversight. At the local level, the challenge is to transform schools into vibrant centres of their community, housing rich learning environments and nurturing social networks. From these centres, a holistic and democratic approach to learning can emerge. Schools would no longer be seen as a public expense but, rather, a lively public place that welcomes children and families before, during and after the ring of the bell. $\mathrm{HQ}$

\section{References}

Campaign 2000. n.d. National Report Cards. Toronto, ON: Author. Retrieved March 03, 2012. <http://www.campaign2000.ca/reportcards.html>.

Fortin , P., L. Godbout and S. St-Cerny. 2011. Economic Consequences of Quebec's Educational Childcare Policy [PowerPoint Slides]. Toronto, ON: University of Toronto. Retrieved March 03, 2012. <http://www. oise.utoronto.ca/atkinson/Events/Economic_Forum.html>.

Gilmore, J. 2010. Trends in Dropout Rates and the Labour Market Outcomes of Young Dropouts. Ottawa, ON: Labour Statistics Division, Statistics Canada.

Government of Australia, Department of Families, Housing, Community Services and Indigenous Affairs. n.d. Stronger Families in Australia Study: The Impact of Communities for Children. Sydney, New South Wales: Author. Retrieved March 03, 2012. <http://www.fahcsia. gov.au/about/publicationsarticles/research/occasional/Documents/ op25/default.htm>.

Harold, G., J. Aitken and H. Shelton. 2007."Inter-parental Conflict and Children's Academic Attainment: A Longitudinal Analysis. Journal of Child Psychology and Psychiatry 48:12:1223-32.

Higgins, C. and L. Duxbury. 2002. The 2001 National Work-Life Conflict Study: Report One. Ottawa, ON: Health Canada.

Janus, M. and E. Duku. 2007. "The School Entry Gap: Socioeconomic, Family, and Health Factors Associated with Children's School Readiness to Learn." Early Education and Development 18(3): 375-403.

Kershaw, P. 2011. Does Canada Work for All Generations? Vancouver, BC: University of British Columbia. Retrieved October 18, 2011. $<$ http://blogs.ubc.ca/newdealforfamilies/new-deal-for-families-2/>.

McCain, M.N. and J.F. Mustard. 1999. Early Years Study: Reversing the Real Brain Drain. Toronto, ON: Ontario Children's Secretariat.

McCain, M.N., J.F. Mustard and S. Shanker. 2007. Early Years Study 2: Putting Science into Action. Vancouver, BC: Council for Early Childhood Development.

McCain, M.N., J.F. Mustard and K. McCuaig. 2011. Early Years Study 3: Making Decisions, Taking Action. Toronto, ON: Margaret and Wallace McCain Family Foundation.

Morrison, W., P. Peterson and R. Morrison. 2012. Two Year Research Report, New Brunswick Early Childhood Centres. Fredericton, NB: University of New Brunswick, Health and Education Research Group.

Offord Centre for Child Studies. n.d.. School Readiness to Learn National SK Cohort Results: Based on the Early Development Instrument Data Collection for Senior Kindergarten Students in Canada, Spring 2008. Hamilton, ON: Author. Retrieved March 4, 2012. <http://www.offordcentre.com/readiness/pubs/2008_11_12_National_SK_Cohort.pdf>.

Organisation for Economic Co-operation and Development. 2006. Starting Strong II. Paris, France: OECD Publishing.
Roy, F. 2006. "From She to She: Changing Patterns of Women in the Canadian Labour Force." Canadian Economic Observer 19(6): 3.1-3.10.

Siraj-Blatchford, I. ,J. Siraj-Blatchford. 2009. Early Years Knowledge Review 3: Improving Development Outcomes for Children through Effective Practice In Integrating Early Years Services. London, England: Centre for Excellence and Outcomes in Children and Young People's Services. Retrieved March 08, 2012<http://www.c4eo.org.uk/themes/ earlyyears/effectivepractice/files/c4eo_effective_practice_kr_1.pdf>

Stack, D., J. Ledingham, A. Serbin, J. Cooperman, C. Temcheff, and C. Schwartzman. 2011. "Predicting Family Poverty and Other Disadvantaged Conditions for Child Rearing from Childhood Aggression and Social Withdrawal: A 30-year Longitudinal Study." International Journal of Behavioral Development 35 (2): 97-106.

Statistics Canada. 2007, June 28. "Canada’s Population Estimates First Quarter 2007 (Preliminary).” The Daily. Retrieved January 13, 2012. $<$ http://www.statcan.gc.ca/daily-quotidien/070628/dq070628c-eng. htm>.

Statistics Canada. 2011. Father's Day ... By the Numbers 2011. Ottawa: ON; Author. Retrieved March 08, 2012. <http://www42.statcan.ca/ smr08/2011/smr08_157_2011-eng.htm>.

Toronto First Duty. 2008. Toronto First Duty: Lessons from the TFD Research. Toronto, ON: Author. Retrieved March 08, 2012. <http:// www.toronto.ca/firstduty/tfd_research_summary.pdf>.

Toronto First Duty. 2009. Research Findings From Phase 2 of Toronto First Duty and Their Implications for Full Day Learning In Ontario. Toronto, ON: Author. Retrieved March 08, 2012. <http://www. toronto.ca/firstduty/research_findings_from_phase_two_tfd $\% 20$. $\mathrm{pdf}>$.

UNICEF. 2008. The Child Care Transition, Innocenti Report Card 8, 2008. Florence, Italy: UNICEF Innocenti Research Centre.

\section{About the Author}

Kerry McCuaig is the Atkinson fellow in early childhood policy at the Ontario Institute for Studies in Education, University ofToronto, in Toronto, Ontario. She is co-author of the Early Years Study 3 and is an expert advisor to the early years work of the Atkinson Charitable Foundation, the Margaret and Wallace McCain Family Foundation and the Early Years Funders Working Group. Kerry also supported the development of Early Years Study 2 (2007), With Our Best Future in Mind (2009), the report to the premier of Ontario on full-day learning and Early Childhood Education and Care, Next Steps (2009), a comprehensive review of early childhood programs by the Senate of Canada. 